\title{
In Vitro Antioxidant Properties of 2-Imino-benzimidazole and 1,3-Thiazolo[3,2-a]benzimidazolone Derivatives
}

\author{
Katarina Tomović ${ }^{1}$, Jelena Mrmošanin², Denitsa Yancheva³ \\ Anelia Ts Mavrova ${ }^{4}$, Andrija Šmelcerović ${ }^{5}$ \\ ${ }^{1}$ University of Niš, Faculty of Medicine, Department of Pharmacy, Niš, Serbia \\ ${ }^{2}$ University of Niš, Faculty of Sciences and Mathematics, Department of Chemistry, Niš, Serbia \\ ${ }^{3}$ Institute of Organic Chemistry with Centre of Phytochemistry, Bulgarian Academy of Sciences, Sofia, Bulgaria \\ ${ }^{4}$ University of Chemical Technology and Metallurgy, Sofia, Bulgaria \\ ${ }^{5}$ University of Niš, Faculty of Medicine, Department of Chemistry, Niš, Serbia
}

\section{SUMMARY}

Antioxidant properties of 2-[2-imino-5-nitro-3-(2-oxo-2-phenylethyl)-2,3-dihydro-1H-benzimidazol1-yl]-1-phenylethanone (compound 1) and 2-(4-fluorobenzylidene)-6-(phenylcarbonyl)[1,3]thiazolo[3,2a]benzimidazol-3(2H)-one (compound 2) were evaluated in vitro. Compounds 1 and 2 did not show significant radical scavenging activity. It has been suggested that antioxidant strategies should not be based on direct scavengers but rather on the potentiation of endogenous antioxidant defenses, or on the reduction of the sources of reactive species. Although a direct scavenging mechanism is missing, the assayed compounds ( 1 and 2$)$ as evidenced inhibitors of xanthine oxidase and dipeptidyl peptidase-4 might act antioxidatively by employing other mechanisms.

Key words: 2-imino-benzimidazoles, 1,3-thiazolo[3,2-a]benzimidazolones, antioxidant activity, antioxidant mechanisms

Corresponding author:

Andrija Šmelcerović

e-mail: a.smelcerovic@yahoo.com

Katarina Tomović

e-mail: katarinat91@gmail.com 


\section{INTRODUCTION}

Oxidative stress occurs when reactive oxygen/ nitrogen species overwhelm antioxidative defenses, leading to oxidative modification of biomacromolecules and tissue injury (1). Aging and the pathogenesis of many diseases, including diabetes mellitus, atherosclerosis and neurodegenerative disorders, have been associated with oxidative stress (2). Reactive oxygen species are derived in many metabolic processes that include xanthine oxidase, uncoupled nitric oxide synthase, nicotinamide adenine dinucleotide phosphate oxidase and mitochondrial respiratory enzymes (3). Modulations of the activity/expression of the mentioned enzymes might decrease oxidative stress burden $(4,5)$.

An antioxidant is a molecule, ion, or a relatively stable radical that is capable of delaying or preventing the oxidation of substrates (proteins, lipids, carbohydrates and DNA). There are many possible mechanisms of antioxidant activity, by hin- dering a generation of reactive species, directly scavenging them, or indirectly by raising the levels of endogenous antioxidant defenses $(2,6,7)$. The enzymatic/nonenzymatic, electron/hydrogen atom transfer-based assays enable the evaluation of the mechanism of antioxidant activity in vitro and in vivo $(1,6)$. Due to the complexity of the research topic, none of a multitude of tests has gained total acceptance (1). The target, the environment, and the source of reactive species are important in the characterization of an antioxidant (6). Assays may be used together to reveal more complete sight on the profile of antioxidative action (1).

Herein, in vitro antioxidant properties of 2-[2imino-5-nitro-3-(2-oxo-2-phenylethyl)-2,3-dihydro1H-benzimidazol-1-yl]-1-phenylethanone (compound 1) and 2-(4-fluorobenzylidene)-6(phenylcarbonyl)[1,3]thiazolo[3,2-a]benzimidazol$3(2 \mathrm{H})$-one (compound 2) (Figure 1) were evaluated in order to assess their free radical scavenging capacity.

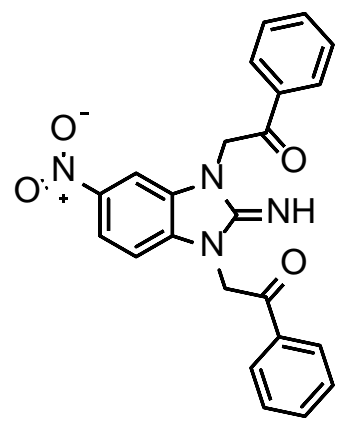

1

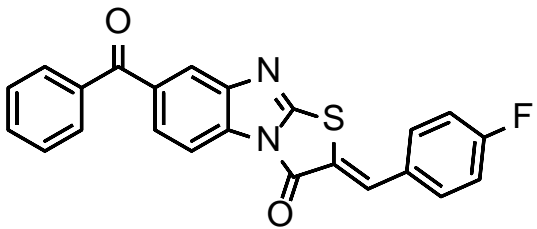

2

Figure 1. Structures of the assayed compounds

\section{MATERIALS AND METHODS}

\section{Chemicals}

The synthesis of the studied 2-imino-benzimidazole and 1,3-thiazolo[3,2-a]benzimidazolone derivative (compounds 1 and 2) was performed, as described in our previous study (8).

6-Hydroxy-2,5,7,8-tetramethylchroman-2-carboxylic acid (trolox), iron(III) chloride hexahydrate and copper(II) chloride dyhidrate were purchased from Acros Organics (Morris Plains, New Jersey, USA). 2,2-Diphenyl-1-picrylhydrazyl (DPPH), 2,2'azino-bis-3-ethylbenzothiazoline-6-sulfonic acid (ABTS), 2,4,6-tris(2-pyridyl)-S-triazine and neocuproine were purchased from Sigma Aldrich (Steineheim, Germa-ny). Glacial acetic acid, ammonium acetate, po-tassium persulfate, iron(II) sulfate heptahydrate, ascorbic acid, hydrochloric acid, ethanol and methanol were purchased from Merck (Darmstadt, Ger-many). 


\section{Evaluation of free radical scavenging activity}

Antioxidant activity of compounds $\mathbf{1}$ and $\mathbf{2}$ was evaluated in vitro using DPPH radical scavenging assay (according to the method of BrandWilliams et al. (9), slightly modified by Miliauskas et al. (10)), ABTS radical cation decolourisation assay (using the method of Re et al. (11) and Arts et al. (12)), cupric reducing antioxidant capacity (CUPRAC) assay (according to the method of Apak et al. (13)) and ferric reducing antioxidant power (FRAP) assay (performed as previously described by Benzie and Strain (14) and modified by Vijayalakshmi and Ruckmani (15)). Ascorbic acid was used as a reference antioxidant. All measurements were done in triplicate. The results were expressed as micromoles of Trolox equivalents (TE) per gram of the sample ( $\mu \mathrm{mol} \mathrm{TE} / \mathrm{g})$ in $\mathrm{DPPH}$ and ABTS assays, as milligrams of TE per gram of the sample (mg TE/g) in CUPRAC assay, and as micromoles of $\mathrm{Fe}^{2+}$ equivalents (FE) per gram of the sample $(\mu \mathrm{mol} \mathrm{FE} / \mathrm{g})$ in FRAP assay.

\section{RESULTS AND DISCUSSION}

In all performed in vitro assays, compounds $\mathbf{1}$ and 2 did not show significant antioxidant activity, in terms of direct scavenging of free radicals, when compared to the ascorbic acid as a reference antioxidant. The highest antioxidant activity of both tested compounds and ascorbic acid was measured in FRAP assay (Table 1).

Ascorbic acid is an antioxidant available in natural sources, with well-established biological functions (16). Among others, data from in vitro and in vivo studies suggest that ascorbic acid might inhibit xanthine oxidase and reduce serum uric acid levels $(17,18)$.

Table 1. In vitro evaluated antioxidant activity of compounds $\mathbf{1}$ and $\mathbf{2}$

\begin{tabular}{c|c|c|c|c}
\hline \hline & $\begin{array}{c}\text { DPPH } \\
(\mu \mathrm{mol} \mathrm{TE} / \mathrm{g})\end{array}$ & $\begin{array}{c}\text { ABTS } \\
(\mu \mathrm{mol} \mathrm{TE} / \mathrm{g})\end{array}$ & $\begin{array}{c}\text { CUPRAC } \\
(\mathrm{mg} \mathrm{TE} / \mathrm{g})\end{array}$ & $\begin{array}{c}\text { FRAP } \\
(\mu \mathrm{mol} \mathrm{FE} / \mathrm{g})\end{array}$ \\
\hline Compound & & & & \\
\hline $\mathbf{1}$ & $0.24 \pm 0.01$ & $13.79 \pm 0.36$ & $22.21 \pm 0.16$ & $66.75 \pm 2.26$ \\
\hline $\mathbf{2}$ & $6.55 \pm 0.08$ & $5.63 \pm 0.18$ & $29.06 \pm 0.16$ & $60.37 \pm 0.75$ \\
\hline & & & & \\
\hline Ascorbic acid & $4760 \pm 68$ & $6695 \pm 108$ & $3173 \pm 52$ & $14227 \pm 132$ \\
\hline \hline
\end{tabular}

Although the tested compounds did not show direct radical scavenging effects to a greater extent in the used assays, it has been evidenced that they act as inhibitors of xanthine oxidase and dipeptidyl peptidase-4 (19), which allows them to act antioxidatively by other mechanisms, suppressing the production of free radicals as well as enhancing endogenous antioxidant defense systems. Besides the inhibition of xanthine oxidase as a producer of reactive species, inhibition of dipeptidyl peptidase- 4 has also been shown to reduce oxidative stress in various disease models in many ways (20).

The impairment of redox homeostasis, increased production of reactive oxygen species and/or weakened antioxidant defense system, associated with reduced NO bioavailability, contribute to vascular dysfunction (21). The levels of reactive oxygen species are determined by the rate of their production and clearance. Direct scavengers of free radicals and antioxidant enzymes (superoxide dismutase, catalase, glutathione peroxidase) participate in the removal of reactive species (22). It has been highlighted that the antioxidant strategies should not be based on the classical antioxidants as direct scavengers, but rather on the elevation of the levels of endogenous antioxidant enzymes, or on the suppression of the sources of reactive species (20). Missing enough effective radical scavenging, but showing other mechanisms of the antioxidant activity, compounds $\mathbf{1}$ and $\mathbf{2}$ assayed here fit into the abovementioned strategy.

\section{CONCLUSION}

Although compounds $\mathbf{1}$ and $\mathbf{2}$ are not sufficiently effective direct scavengers of free radicals, they act antioxidatively as inhibitors of xanthine oxidase, by which the generation of free radicals is 
downregulated, and as inhibitors of dipeptidyl peptidase-4, which allows them to act antioxidatively by different mechanisms. The absence of substantial body of good results in the in vitro evaluation of direct reactive species scavenging means that this mechanism of antioxidant activity is missing. Direct scavenging is not more important when compared to other mechanisms, and it is not enough as the only way of action.

\section{Acknowledgements}

The financial support of this work by the project of the Ministry of Education, Science and Technological Development of the Republic of Serbia (numbers 451-03-68/2020-14/200113 and 451-03$68 / 2020-14 / 200124)$ and Internal project No. 40 of the Faculty of Medicine of the University of Niš is gratefully acknowledged.

\section{References}

1. Apak R, Ozyürek M, Güçlü K et al. Antioxidant activity/capacity measurement. 1. Classification, physicochemical principles, mechanisms, and electron transfer (ET)-based assays. J Agric Food Chem 2016; 64: 997-1027. https://doi.org/10.1021/acs.jafc.5b04739

2. Pinchuk I, Shoval H, Dotan $Y$ et al. Evaluation of antioxidants: scope, limitations and relevance of assays. Chem Phys Lipids 2012; 165: 638-47. https://doi.org/10.1016/j.chemphyslip.2012.05.003

3. Togliatto G, Lombardo G, Brizzi MF. The future challenge of reactive oxygen species (ROS) in hypertension: from bench to bed side. Int J Mol Sci 2017; 18: 1988.

https://doi.org/10.3390/ijms18091988

4. Battelli MG, Polito L, Bolognesi A. Xanthine oxidoreductase in atherosclerosis pathogenesis: not only oxidative stress. Atherosclerosis 2014; 237: 562-7.

(http://dx.doi.org/10.1016/j.atherosclerosis.2014.10.006)

5. George J, Struthers AD. Role of urate, xanthine oxidase and the effects of allopurinol in vascular oxidative stress. Vasc Health Risk Manag 2009; 5: 265-72.

\section{https://doi.org/10.2147/VHRM.S4265}

6. Cadenas E, Packer L, editors. Handbook of antioxidants. Second edition revised and expanded. Marcel Dekker, Inc, 2002.

7. Haida Z, Hakiman M. A comprehensive review on the determination of enzymatic assay and nonenzymatic antioxidant activities. Food Sci Nutr 2019; 7: 1555-63.

https://doi.org/10.1002/fsn3.1012

8. Mavrova AT, Yancheva D, Anastassova $\mathrm{N}$ et al. Synthesis, electronic properties, antioxidant and antibacterial activity of some new benzimidazoles. Bioorg Med Chem 2015; 23: 631726.

https://doi.org/10.1016/j.bmc.2015.08.029

9. Brand-Williams W, Cuvelier ME, Berset CL. Use of a free radical method to evaluate antioxidant activity. LWT - Food Sci Technol 1995; 28: 25-30. (https://doi.org/10.1016/S0023-6438(95)80008-5)

10. Miliauskas G, Venskutonis PR, Van Beek TA. Screening of radical scavenging activity of some medicinal and aromatic plant extracts. Food Chem 
2004; 85: 231-7.

https://doi.org/10.1016/j.foodchem.2003.05.007

11. Re R, Pellegrini N, Proteggente A et al. Antioxidant activity applying an improved ABTS radical cation decolorization assay. Free Radic Biol Med 1999; 26: 1231-7.

(https://doi.org/10.1016/S0891-5849(98)00315-3)

12. Arts MJ, Haenen GR, Voss HP et al. Antioxidant capacity of reaction products limits the applicability of the Trolox Equivalent Antioxidant Capacity (TEAC) assay. Food Chem Toxicol 2004; 42: 45-9.

https://doi.org/10.1016/j.fct.2003.08.004

13. Apak R, Güclü K, Özyürek M et al. Mechanism of antioxidant capacity assays and the CUPRAC (cupric ion reducing antioxidant capacity) assay. Microchim Acta 2008; 160: 413-9.

(https://doi.org/10.1007/s00604-007-0777-0)

14. Benzie IF, Strain JJ. Ferric reducing/antioxidant power assay: direct measure of total antioxidant activity of biological fluids and modified version for simultaneous measurement of total antioxidant power and ascorbic acid concentration. Methods Enzymol 1999; 299: 15-27. (https://doi.org/10.1016/S0076-6879(99)99005-5)

15. Vijayalakshmi M, Ruckmani K. Ferric reducing anti-oxidant power assay in plant extract. Bangladesh J Pharmacol 2016; 11: 570-2. (https://doi.org/10.3329/bjp.v11i3.27663)

16. Gulcin İ. Antioxidants and antioxidant methods: an updated overview. Arch Toxicol 2020; 94: 651-715. (https://doi.org/10.1007/s00204-020-02689-3)

17. Feigelson P. The inhibition of xanthine oxidase in vitro by trace amounts of $l$-ascorbic acid. J Biol Chem 1952; 197: 843-50.

(https://www.jbc.org/content/197/2/843.full.pdf)

18. Roumeliotis S, Roumeliotis A, Dounousi E et al. Dietary antioxidant supplements and uric acid in chronic kidney disease: a review. Nutrients 2019; 11: 1911.

(https://doi.org/10.3390/nu11081911)

19. Tomovic K, Ilic BS, Smelcerovic $Z$ et al. Benzimidazole-based dual dipeptidyl peptidase-4 and xanthine oxidase inhibitors. Chem Biol Interact 2020; 315: 108873.

(https://doi.org/10.1016/j.cbi.2019.108873)

20. Steven S, Münzel T, Daiber A. Exploiting the pleiotropic antioxidant effects of established drugs in cardiovascular disease. Int J Mol Sci 2015; 16: 18185-223.

(https://doi.org/10.3390/ijms160818185)

21. Szocs K. Endothelial dysfunction and reactive oxygen species production in ischemia/ reperfusion and nitrate tolerance. Gen Physiol Biophys 2004; 23: 265-96.

22. Pickering RJ, Rosado CJ, Sharma A et al. Recent novel approaches to limit oxidative stress and inflammation in diabetic complications. Clin Transl Immunol 2018; 7: e1016. (https://doi.org/10.1002/cti2.1016) 


\title{
Antioksidativna aktivnost 2-imino-benzimidazol i 1,3-tiazolo[3,2-a]benzimidazolon derivata: in vitro studija
}

\author{
Katarina Tomović ${ }^{1}$, Jelena Mrmošanin², Denitsa Yancheva³ \\ Anelia Ts Mavrova ${ }^{4}$, Andrija Šmelcerović ${ }^{5}$ \\ ${ }^{1}$ Univerzitet u Nišu, Medicinski fakultet, Katedra Farmacija, Niš, Srbija \\ ${ }^{2}$ Univerzitet u Nišu, Prirodno-matematički fakultet, Departman za Hemiju, Niš, Srbija \\ ${ }^{3}$ Institut za organsku hemiju sa Centrom za fitohemiju, Bugarska akademija nauka, Sofija, Bugarska \\ ${ }^{4}$ Univerzitet za hemijske tehnologije i metalurgiju, Sofija, Bugarska \\ ${ }^{5}$ Univerzitet u Nišu, Medicinski fakultet, Katedra Hemija, Niš, Srbija
}

\section{S A ŽETAK}

Antioksidativna aktivnost 2-[2-imino-5-nitro-3-(2-okso-2-feniletil)-2,3-dihidro-1H-benzimidazol-1-il]1-feniletanona (jedinjenje 1) i 2-(4-fluorobenziliden)-6-fenilkarbonil)[1,3]tiazolo[3,2-a]benzimidazol-3(2H)ona (jedinjenje 2) ispitivana je in vitro. Jedinjenja 1 i 2 nisu pokazala značajnu efikasnost u direktnom uklanjanju slobodnih radikala. Pretpostavka je da antioksidativne strategije ne bi trebalo da budu zasnovane na antioksidansima, koji uklanjaju radikale direktno, već na jačanju endogene antioksidativne odbrane ili na inhibiranju izvora reaktivnih vrsta. Iako izostaje efikasnost u direktnom uklanjanju radikala, ispitivana jedinjenja (1 i 2), kao dokazani inhibitori ksantin oksidaze i dipeptidil peptidaze-4 mogu da pokazuju antioksidativnu aktivnost drugim mehanizmima.

Ključne reči: 2-imino-benzimidazoli, 1,3-tiazolo[3,2-a]benzimidazoloni, antioksidativna aktivnost, antioksidativni mehanizmi 